\title{
DDT and Its Metabolites in Fresh Water Fish Samples
}

\author{
Md. Amjad Hossain, Mohammad Shoeb and Nilufar Nahar \\ Department of Chemistry, University of Dhaka, Dhaka, Bangladesh
}

\begin{abstract}
Twenty two fresh water fish samples namely Puntius sarana (Shawrputi), Cyprinus carpio (Karp), Oreochromis niloticos (Telapia), Channa punctatus (Taki), Wallogonia attu (Boal), Eutropiichthys vacha (Bacha), Macrognathus aculiatus (Baim), Ailia coila (Kajoli), Mystus cavasisus(Gulsa), Ompok pabda (Pabdha), Corica soborna (Kachki), Mystus vittatus (Tengra), Glossogobius giuris (Baila), Macrobrachium malcolmsli (Chingri), Amblypharyngodon microlepis (Mola), Anabas testudineus (Koi), Macrognathus aculiatus (Baim), Channa striatus (Shole), Heteropnueste fossilis (Shing), Puntius sophore (Small Puti) and Pseudambassis ranga (Telapia) were collected from two rivers and one cultured fish pond. The samples were extracted by QuEChERS method, cleaned up with conc. $\mathrm{H}_{2} \mathrm{SO}_{4}$ treatment and cleaned extracts were analyzed by GC-ECD. Small size cultured rui fish sample which did show detectable amount of DDT and its metabolites was used for the recovery experiments. Percent recovery was found to be in the range of 70\%-113\%. Amount of total DDTs were found to be 54.34, 48.81, 62.09, 54.72,78.81, 60.07, 47.0, 42.7, 26.31, 10.36, 25.32, 12.96, 20.10, 12.78, 17.65, and 4.71, 8.58, 11.3 and $19.01 \mathrm{ng} / \mathrm{g}$ in gulsa, pabhda, baila, bacha, baim, small puti, tengra, chanda, kachki, boal, taki, chingri, mola, shole, shing, koi, swarputi, karp and telapia fish samples, respectively. However, the residual amounts of DDTs in all the fish samples were below maximum residue limit (MRL of DDTs in fish $5.0 \mathrm{mg} / \mathrm{kg}$ ) according to Codex Alimentarius Commission. The ratios of 4,4'-DDT/DDTs were in the range of 0.03-0.44 which indicated that exposure to DDT is not due to recent use.
\end{abstract}

Key words: OCPs, biomagnification, gas chromatography, fresh water fish and food chain.

\section{Introduction}

Organochlorine Pesticides (OCPs), highly stable and bio-accumulative compounds were identified as hazardous environmental contaminants for decades [1, 2]. As Bangladesh is an agricultural country, these compounds were used in the country from the middle of the 1950's in agriculture to increase crop production and other purposes including controlling vector diseases [3]. It is long persistence in the environment and transport long distances via air, water and sediment. The major exposure of the persistent OCPs to humans is via contaminated food, drinking water, inhalation and dermal uptake [2, 4]. OCPs including DDT have been banned in Bangladesh after signing Stockholm Convention [4, 5]. Aquatic ecosystems in Bangladesh are very much susceptible for being contaminated with pesticides and other pollutants. Pesticides enter into the aquatic systems either by direct discharge or transported by

Corresponding author: Mohammad Shoeb, professor, research fields: analytical and environmental chemist. evaporation and/or run-off processes [4]. DDT and its metabolites are not soluble in water but can be present as suspended materials associated with the phytoplankton, algae or through adsorption on soil or sediment [2, 3]. Fish and other aquatic organism can easily be contaminated by taking these suspended materials as their food [1]. Fish is one of the important bio-indicator of bioaccumulation of organic pollutants in fatty tissues and it is one of the sources for accumulation of DDTs to human blood through food chain. Presence of DDT and its metabolites were reported by our research group in fresh \& dry fish, chicken meat and human blood samples [7-11]. In continuation of our work on chemical contaminants in food and environment, we are now reporting the presence of DDTs in 22 fresh water fish samples from two different rivers and cultured water pond.

\section{Materials and Methods}

\subsection{Sample Collection}

Twenty two live fish samples were collected from 
Mohangonj (Kangsha river) and Brahmanbaria (Titas river and cultured fish pond). The collected fish samples were kept in jip-locked plastic bag with label in chill-box then transported to the laboratory and stored in the freezer at $-20^{\circ} \mathrm{C}$ until extraction carried out. Name sizes, place of collection are given Table 1.

\subsection{Chemicals, Reagents and Solvents}

The certified standards; 2,4-DDT, 4,4'-DDT, 4,4'-DDE and 4,4'-DDD (99\% purity) were purchased from Dr. Ehrenstorfer, Germany. Analytical grade anhydrous magnesium sulfate, sodium sulfate were purchased from Scharlau, Spain. Analytical grade solvent such as hexane and acetone were purchased from Sigma Aldrich. Sulfuric acid (98\%) and sodium chloride were purchase from Merck, Germany.

\subsection{Apparatus and Equipment}

All evaporations were carried out by rotary vacuum evaporator at water bath temperature not exceeding 40 ${ }^{\circ} \mathrm{C}$. The residual solvent of the dried mass was removed by a freeze dryer (Adward, RV12). Anhydrous sodium and magnesium sulphates were heated at $300{ }^{\circ} \mathrm{C}$ in a furnace (Carbolite, GSM 11/8 Hope valley, S336 RB, England). For 4 hours and dried materials were kept in a vacuum desiccators.

Calibrated balance, volumetric flasks and pipettes (calibrated by BSTI) were used for the analysis. Gas Chromagraph (Shimadzu 2010) coupled with Electron Captured Detector (GC-ECD) used for analysis was calibrated by local agent of the company (AQC).

A Gas Chromatograph (GC-2010 Shimadzu) coupled with Electron Capture detector, (GC-ECD) was

Table 1 Fish samples collected from Mohangonj and Brahmanbaria.

\begin{tabular}{|c|c|c|c|}
\hline \multicolumn{4}{|c|}{ Fish samples Kangsha river } \\
\hline Serial No. & Scientific name & Local name & Size $(\mathrm{cm})$ \\
\hline 1 & Channa punctatus (Carnivore) & Taki & $27.0-28.0$ \\
\hline 2 & Wallogonia attu (Carnivore) & Boal & 46.0 \\
\hline 3 & Eutropiichthys vacha (Carnivore) & Bacha & $16.0-17.7$ \\
\hline 4 & Macrognathus aculiatus (Omnivore) & Baim & $11.0-12.0$ \\
\hline 5 & Ailia coila (Omnivore) & Kajoli & $12.0-13.2$ \\
\hline 6 & Mystus cavasisus (Omnivore) & Gulsa & $12.0-12.5$ \\
\hline 7 & Ompok pabda (Omnivore) & Pabdha & $6.0-6.5$ \\
\hline 8 & Corica soborna (Omnivore) & Kachki & $<2.9$ \\
\hline \multicolumn{4}{|c|}{ Fish samples of Titas river } \\
\hline 9 & Mystus vittatus (Omnivore) & Tengra & $8.0-8.4$ \\
\hline 10 & Channa punctatus (Carnivore) & Taki & $17.0-17.8$ \\
\hline 11 & Glossogobius giuris (Carnivore) & Baila & $11.0-12.5$ \\
\hline 12 & $\begin{array}{l}\text { Macrobrachium malcolmsli (Carnivore) } \\
\text { Chingri) }\end{array}$ & Chingri & $<3.9$ \\
\hline 13 & Amblypharyngodon microlepis (Hervivore) & Mola & $<3.7$ \\
\hline 14 & Anabas testudineus (Omnivore) & Koi & $11.0-11.5$ \\
\hline 15 & $\begin{array}{l}\text { Macrognathus aculiatus (Omnivore) } \\
\text { Omnivore) }\end{array}$ & Baim & $11.0-12.5$ \\
\hline 16 & Channa striatus (Carnivore) & Shole & 34.0 \\
\hline 17 & Heteropnueste fossilis (Omnivore) & Shing & 14.4-15.0 \\
\hline 18 & Puntius sophore (Omnivore) & Small Puti & $9.0-10.2$ \\
\hline 19 & Pseudambassis ranga (Omnivore) & Chanda & $<3.3$ \\
\hline \multicolumn{4}{|c|}{ Fish samples from cultured in reserved water body of Brahmanbaria } \\
\hline 20 & Puntius sarana (Herbivore) & Shawrputi & $21.2-22.0$ \\
\hline 21 & Cyprinus carpio (Herbivore) & Karp & $26.0-27.0$ \\
\hline 22 & Oreochromis niloticos (Omnivore) & Telapia & $22.0-23.5$ \\
\hline
\end{tabular}


used for analysis. Separations were performed on HP-5 quartz capillary column (30 m long $\times 250 \mu \mathrm{m}$ i.d: $0.25 \mu \mathrm{m}$ film thicknesses), nitrogen was used as carrier (column flow $1.92 \mathrm{~mL} / \mathrm{min}$.) as well as make up gas. The injector and detector temperatures were set $250{ }^{\circ} \mathrm{C}$ and $260{ }^{\circ} \mathrm{C}$, respectively and the oven temperature was programmed as $120{ }^{\circ} \mathrm{C}$ ( 1 min hold) to $250{ }^{\circ} \mathrm{C}$ ( $4 \mathrm{~min}$ hold) and $10{ }^{\circ} \mathrm{C}$ rise per min. All the injections $(1 \mu \mathrm{L})$ were done in split-less/spit mode. Identifications of the analyte samples were done by comparing retention time of corresponding certified standard samples and quantification by using external calibration curves of the corresponding reference samples.

\subsection{Extractions and Clean-up}

Large fish samples were divided into head, abdominal and dorsal parts and small fish whole samples were taken for analysis. Each of the fish sample was homogenized by a kitchen blender 60-70 $\mathrm{g}$ in each jip lock bag was kept in a freezer until analysis carried out. A part of each of the fish samples was freeze died.

Freeze dried fish samples (10 g) was refluxed with n-hexane $(60 \mathrm{~mL} \times 3 ; 30 \mathrm{~min}$ each time). The combined n-hexane extract was evaporated to dryness and percent fat content was determined and expressed on fresh weight basis (Tables 2 and 3).
Fish sample (10 $\mathrm{g} \times 3$ for replicate study was taken out from the freezer, thawed and extracted by QuEChERS (Quick, Easy, Coheap, Effective, Rugged and Safe) method [12]. The extract was cleaned with sulphuric acid treatment [13]. The cleaned extract was analysed by GC-ECD. Standard deviations were calculated from three replicate analysis (Tables 2 and 3).

\subsection{LOD, LOQ and Recovery Experiment}

Primary standard solutions $\left(500 \mu \mathrm{g} \quad \mathrm{L}^{-1}\right)$ of 2,4-DDT, 4,4-DDT, 4,4-DDE and 4,4-DDD were prepared in n-hexane in calibrated $100 \mathrm{~mL}$ volumetric flask. These primary standard solutions were diluted to the middle (100 $\mu \mathrm{g} \mathrm{L}^{-1}$ ) and working standard solutions (10 $\mu \mathrm{g} \mathrm{\textrm {L } ^ { - 1 }}$ ), respectively. The working standard solution was serially diluted and the diluted solutions were injected in GC-ECD, LOD (3 times higher than noise), LOQ (3 times higher than LOD) were found out and calibration curves were made.

Residual amount of DDT and its metabolites residues determination were done within the Linearity range $\left(0.025-1,600 \mu \mathrm{g} \mathrm{L}{ }^{-1}\right)$ with an $r^{2}$ (regression coefficient) value were in the range of 0.986-0.999 of the corresponding standards. Three replicate studies were done for each samples and standard deviation were calculated. The LOD and LOQ for all DDT standards were found to be $0.0625 \mathrm{ng} / \mathrm{g}$ and 0.2063 ng/g, respectively.

Table 2 Residual amounts of DDTs in the fish samples collected from Kangsha river.

\begin{tabular}{|c|c|c|c|c|c|c|}
\hline \multirow{2}{*}{ Fish samples } & \multicolumn{5}{|c|}{ Amount of DDT and its metabolites (ng/g) in fresh weight basis } & \multirow{2}{*}{$\begin{array}{l}\text { Fat }(\%) \text { fresh } \\
\text { weight basis }\end{array}$} \\
\hline & 4, 4 -DDE & 4,4-DDD & 2, 4-DDT & 4,4-DDT & $\Sigma \mathrm{DDT}$ & \\
\hline Taki abdominal & $4.36 \pm 0.17$ & $4.32 \pm 0.24$ & $2.99 \pm 0.48$ & $3.36 \pm 0.46$ & 15.03 & 2.78 \\
\hline Taki dorsal & $4.91 \pm 0.64$ & $4.47 \pm 0.73$ & $1.30 \pm 0.09$ & $1.88 \pm 0.14$ & 12.56 & 2.05 \\
\hline Taki head & $2.86 \pm 0.14$ & $3.01 \pm 0.09$ & $0.85 \pm 0.03$ & $1.81 \pm 0.04$ & 8.53 & 4.89 \\
\hline Gulsha & $7.01 \pm 0.91$ & $9.13 \pm 0.79$ & $14.15 \pm 1.17$ & $24.03 \pm 1.30$ & 54.32 & 1.58 \\
\hline Kachki & $4.05 \pm 0.26$ & $4.15 \pm 0.30$ & $8.55 \pm 0.59$ & $9.56 \pm 0.37$ & 26.31 & 2.09 \\
\hline Pabdha & $9.71 \pm 0.69$ & $5.69 \pm 0.35$ & $16.33 \pm 4.68$ & $17.08 \pm 0.60$ & 48.81 & 1.00 \\
\hline Boal abdominal & $6.18 \pm 0.30$ & $1.76 \pm 0.03$ & $0.86 \pm 0.04$ & $1.21 \pm 0.02$ & 11.01 & 0.49 \\
\hline Boal dorsal & $9.71 \pm 0.69$ & $1.21 \pm 0.03$ & $0.66 \pm 0.04$ & $0.64 \pm 0.09$ & 10.22 & 0.27 \\
\hline Boal head & $4.69 \pm 0.07$ & $2.82 \pm 0.21$ & $1.05 \pm 0.05$ & $1.80 \pm 0.25$ & 12.36 & 0.34 \\
\hline Kajoli & $2.26 \pm 0.32$ & $20.53 \pm 0.83$ & $2.51 \pm 0.11$ & $6.71 \pm 0.21$ & 32.01 & 5.80 \\
\hline Baila & $9.75 \pm 0.48$ & $14.38 \pm 0.66$ & $12.61 \pm 0.42$ & $25.35 \pm 0.56$ & 62.09 & 0.75 \\
\hline Bacha & $20.15 \pm 1.51$ & $13.57 \pm 1.08$ & $7.68 \pm 0.30$ & $13.32 \pm 0.65$ & 54.72 & 6.58 \\
\hline
\end{tabular}


Table 3 Residual amounts of DDTs in the fish samples of Titas river and reserved water body.

\begin{tabular}{|c|c|c|c|c|c|c|}
\hline \multirow{2}{*}{ Fish samples } & \multicolumn{5}{|c|}{ Amount of DDT and its metabolites (ng/g) in fresh weight basis } & \multirow{2}{*}{$\begin{array}{l}\text { Fat (\%) fresh } \\
\text { weight basis }\end{array}$} \\
\hline & 4,4-DDE & 4,4-DDD & 2,4-DDT & 4,4-DDT & $\Sigma$ DDT & \\
\hline Taki & $6.26 \pm 0.31$ & $8.79 \pm 0.19$ & $0.18 \pm 0.00$ & $10.09 \pm 0.46$ & 25.32 & 1.64 \\
\hline Baila & $4.70 \pm 0.11$ & $4.82 \pm 0.35$ & $0.31 \pm 0.00$ & $0.55 \pm 0.05$ & 10.38 & 0.76 \\
\hline Chingri & $4.63 \pm 0.47$ & $4.18 \pm 0.24$ & $1.92 \pm 0.04$ & $2.23 \pm 0.06$ & 12.96 & 0.75 \\
\hline Mola & $12.06 \pm 0.75$ & $6.20 \pm 0.29$ & $0.65 \pm 0.03$ & $1.19 \pm 0.04$ & 20.10 & 4.43 \\
\hline Koi & $1.55 \pm 0.04$ & $1.71 \pm 0.04$ & $0.2 \pm 40.03$ & $1.21 \pm 0.05$ & 4.710 & 5.42 \\
\hline Baim & $33.92 \pm 1.37$ & $37.25 \pm 3.35$ & $4.73 \pm 0.33$ & $2.91 \pm 0.04$ & 78.81 & 3.29 \\
\hline Shole & $3.57 \pm 0.41$ & $3.98 \pm 0.41$ & $0.17 \pm 0.04$ & $5.06 \pm 0.49$ & 12.78 & 0.94 \\
\hline Small Puti & $11.03 \pm 0.44$ & $22.69 \pm 0.44$ & $0.61 \pm 0.04$ & $25.74 \pm 0.59$ & 60.07 & 5.78 \\
\hline Tengra & $19.93 \pm 1.40$ & $22.16 \pm 1.40$ & $0.49 \pm 0.03$ & $4.41 \pm 0.33$ & 46.99 & 6.63 \\
\hline Shing & $7.81 \pm 0.48$ & $7.84 \pm 0.48$ & $0.31 \pm 0.00$ & $1.69 \pm 0,07$ & 17.65 & 1.52 \\
\hline Chanda & $12.19 \pm 1.33$ & $19.73 \pm 1.75$ & $3.33 \pm 0.45$ & $7.62 \pm 0.79$ & 42.87 & 2.75 \\
\hline Telapia & $8.75 \pm 0.26$ & $6.79 \pm 0.72$ & $0.63 \pm 0.03$ & $2.84 \pm 0.17$ & 19.01 & 3.79 \\
\hline Karp & $8.22 \pm 0.43$ & $2.69 \pm 0.13$ & BDL & $0.39 \pm 0.04$ & 11.3 & 2.17 \\
\hline Swarputi & $2.82 \pm 0.23$ & $2.73 \pm 0.06$ & $1.42 \pm 0.05$ & $1.61 \pm 0.05$ & 8.58 & 6.39 \\
\hline
\end{tabular}

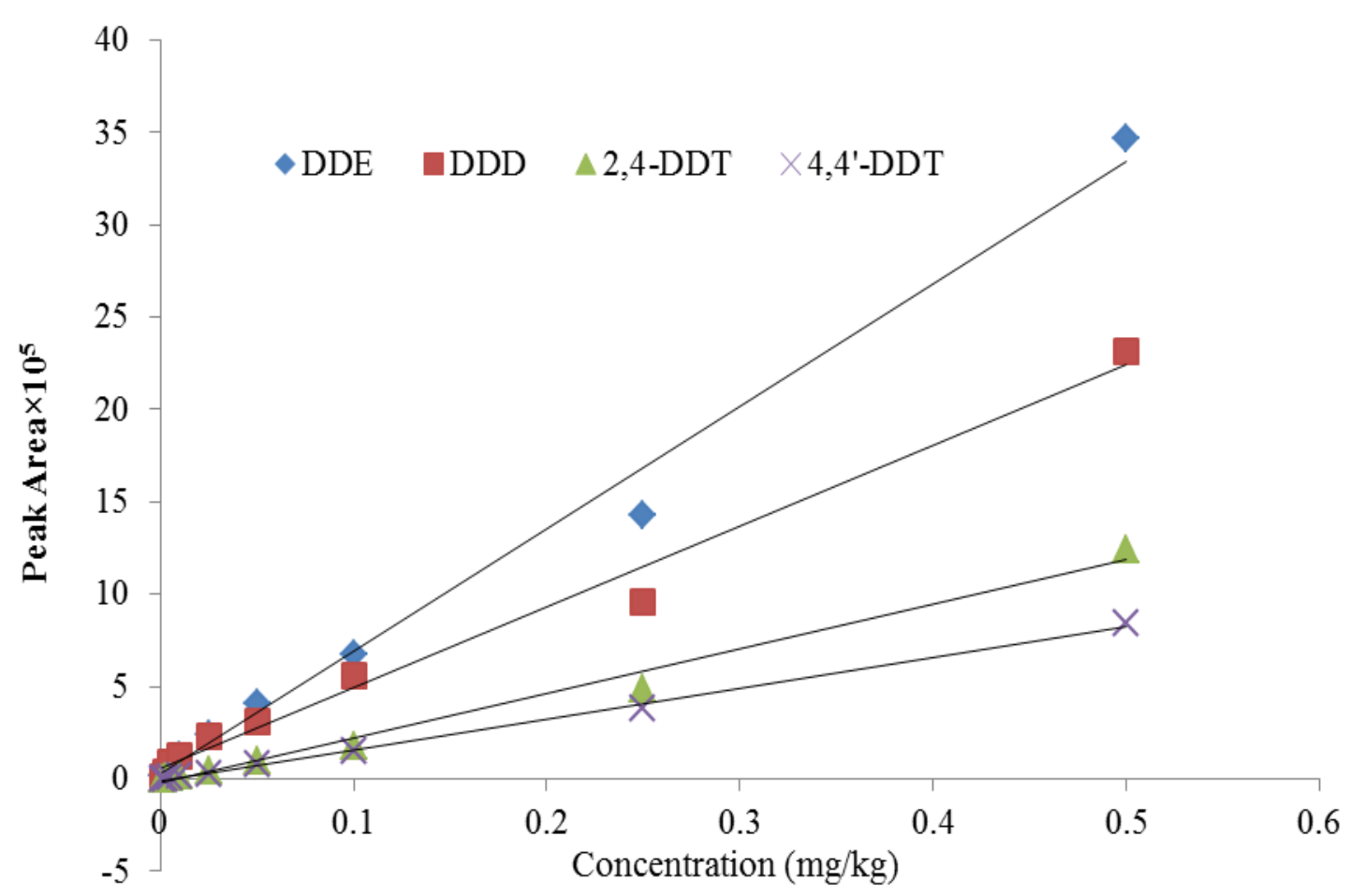

Fig. 1 Calibration curves of standard DDTs solutions.

For recovery experiments, three Nola Fishes (Labeo rohita) were collected from Anandha Bazar (Dhaka city) as a blank fish matrix. Then fishes were made bone free and blended in kitchen blender and $10 \mathrm{~g}$ was used. Known amount of standard DDTs solutions (1.0 $\mathrm{mL}$ of $2.0 \mathrm{ppm}, 1.0 \mathrm{ppm}$ and $0.5 \mathrm{ppm}$ ) were spiked to the fish tissue and allowed the sample to stand for $1 \mathrm{~h}$ to let the pesticides be absorbed into the samples. The samples were extracted and cleaned-up by following the same procedure as described above and made final volume $1.0 \mathrm{~mL}$. The recovery of the each analyte was calculated according to the following formula:

$$
\mathrm{R}=\frac{A m \times C s t \times 100}{A s t \times C m \times M s t}
$$


Where $R$ is the recovery (\%), $A_{m}$ is the peak area of the analyte in the matrix, $A_{s t}$ is the peak area of the analyte in the standard, $C_{m}$ is the concentration of the analyte in the matrix, $C_{s r}$ is the concentration of the analyte in the standard, and $M_{s t}$ is the spiking level (mg/kg). The percentage recoveries for fish samples were found to be $88 \%-92 \%, 101 \%-113 \%$, $76 \%-104 \%$ and 70\%-90\% for 2,4-DDT, 4, 4-DDE, 4, 4-DDD, and 4,4-DDT, respectively.

\section{Results and Discussion}

Nineteen fish samples from two revers Kangsha (Mohonganj) and Titas (Brahmanbaria) were selected to find out overview of environmental contaminants in two different areas. Three fish samples cultured fish ponds were taken to evaluate contaminants which get fish feed and grow faster than naturally live fishes. Most of the small indigenous fishes were adult in their size and size of two large fish samples, boal and shole were also adult size.

Boneless flesh part of large fish and cultured fish samples were studied for DDT and metabolites whereas in case of small indigenous fish samples total edible parts including head were taken.

Calibrated all the apparatus, balance and the GC-ECD were used during the experiments. Certified standards were used for qualitative and quantitative analysis of the fish samples. Three replicate analyses were done for each of the analysis and standard deviation was calculated are satisfactory level. Regression coefficient, $\mathrm{r}^{2}$ were 0.996 for $4,4 \mathrm{DDE}$, 0.997 for 4,4 -DDD, 0.995 for 2,4 -DDT and 0.999 for 4,4-DDT. Linearity of the curves was within acceptable limit. Percent recovery of the standards were $70 \%-113 \%$, which were in the range $70 \%-120 \%$ and acceptable for fish samples according to standard methodology.

DDT and its metabolites varied from sample to sample. Small fish adult samples showed the presence higher amount DDTs than other fish samples. The DDTs accumulation depends on mainly on fat content as they deposit in fatty tissue of fishes. Other factors like food habit, lipid content, digestion metabolism rate, excretion rate and habitat etc. also contribute to DDT accumulation in fish species [6]. In the herbivorous small puti and mola fishes, higher amount of fat content is responsible for higher amount of DDTs. Furthermore, the mola fish was found extensively in rivers, canals, bees and pond throughout the country [7]. The baila and bacha are carnivorous [6, 14] and feed is small fishes, crustaceans and molasses. As we know that DDT is biomagnified sometimes 7,000 times greater in the top consumer to first consumer. These two fishes are on the top position in the food chain and contained the higher value. The lowest value of DDTs is found in shole, taki and boal, these three are highly carnivorous. As we mentioned previous DDT accumulation depends on not only food habit but also on metabolism rate, excretion rate and fat content. In these two fishes their metabolism and excretion rate is higher [6] and fat content also too low. Therefore, although these are carnivorous, the contained lower amount of DDTs. The telapia, karp and swarputi are cultured fishes and they all contain comparatively lower amount of DDTs (Table 3) although they are omnivorous and contained higher amount of fat (expect Karp fish, it contained low amount of fat, Table 3). Thus in cultured fishes DDTs residue is comparatively low than that of marine and river fishes. The amounts of DDTs content were varied in different part of the same fish. In taki and boal fish samples, the abdominal part contained higher amount of DDTs than their dorsal and head parts (Table 2). Thus in cultured fishes DDTs residue is comparatively low than that of marine and river fishes. However, the residual DDTs in all the fish samples were below maximum residue limit (MRL) of DDTs in fish $(5,000$ ng/g Codex Alimentarius, 1993) [15], but continuous consumption of such fishes may cause a threat to human health as a result of biomagnifications. As DDT is a long persistent and bioaccumulative substance in 
the environment, intake of significant amount of this slow poison with our diet is a matter of health concern.

It was found that, the range of fat contents in fish samples was found to be $0.27 \%-6.63 \%$ (Tables 2 and 3). The Tengra (6.63\%) fish and the boal (head, 0.27\%) fish contained the highest and lowest amount fat respectively. The values of fat content were varied in different part of the same fish sample. In case of taki fish, fat content in head part was more (4.89\%) than that of abdominal (2.78\%) and dorsal part (2.05\%). In case of boal fish, fat content was higher in abdominal part $(0.59 \%)$ and other two were comparable (0.27-0.34\%). Besides, other fishes like bacha (6.58\%), swarputi (6.63\%), koi (5.42\%), small puti (5.69\%), mola (4.43\%) and kajoli (5.80\%) contained higher amount of fat. On the other hand, boal, shole, baila, pabdha and shing contained very low amount of fat.

\section{Conclusions}

From the present study, the residual amount of DDT and its metabolites were found in cultured fishes lower than river fish samples. Furthermore, the overall results of DDTs are lower than previous studies. Thus, extensive and indiscriminate uses of organochlorine pesticides especially DDT is decreasing day by day. This study was area-specific giving a holistic picture of the floodplains of our country. The further work is required to determine the overall picture of the pollutants in aquatic environment of Bangladesh.

\section{Acknowledgement}

The authors are grateful to International Science Programme (ISP), University of Uppsala, Uppsala, Sweden and Higher Equation Quality Enhancement Project (HEQEP) for financial support.

\section{References}

[1] Beyer, A., Mackay, D., Matthies, M., Wania, F., and Webster, E. 2000. "Assessing Long-Range Transport Potential of Persistent Organic Pollutants.” Environmental Sciences \& Technology 34 (4): 699-703.
[2] Kelly, B. C., Ikonomou, M. G., Blair, J. D., Morin, A. E., and Gobas, F. A. P. C. 2007. "Food Web-Specific Biomagnification of Persistent Organic Pollutants.” Science 317: 236-9.

[3] Nahar, N. 2006. "Survey and Research on DDT and PCBs in Food Items and Environmental Samples.” Department of Environment, Ministry of Environment and Forests, Government of Bangladesh.

[4] Stockholm Convention on Persistent Organic Pollutants, United Nations Treaty, May 22, 2001, Stockholm, Sweden.

[5] Chowdhury, M. A. Z., Amin-ud-Din, M., Malek, M. A., and Zaman, M. A. 2010. "DDT Residue and Its Metabolites in Dried Fishes of Dhaka City Markets.” Journal of Soil \& Environment 29 (2): 117-21.

[6] Rahman, A. K. A. 1998. Zoological Society of Bangladesh, 2nd edition, reg. No. Dha-07564.

[7] Nahar, N., Mamun, M. I. R., Zamir, R., and Mosihuzzaman, M. 2008 "Analysis of Pesticide Residues in Some Local Fish and Vegetable." The Dhaka University Journal of Science 6 (2): 1-4.

[8] Zamir, R., Hossain, M., Shoeb, M., Mosihuzzaman, M., and Nahar, N. 2013. "Organochlorine Pesticides in Three Fish Samples.” The Dhaka University Journal of Science 61 (2): 215-6

[9] Shoeb, M., Nahar, N., Mandal, S., Sarma, H. M., and Seraji, M. S. I. 2009. "Nitrofuran Antibiotics and Organochlorine Pesticides in Fish and Poultry Fish, Feed Ingredients, and Water Samples Collected from Shrimp Cultivation Area." Journal of Bangladesh Chemical Society 22 (1): 1-8.

[10] Linderholm, L., Jakobsson, K., Lundh, T., Zamir, R., Shoeb, M., Nahar, N., and Bergman, A. 2011. "Environmental Exposure to POPs and Heavy Metals in Urban Children from Dhaka, Bangladesh.” Journal of Environment Monitoring 13 (10): 2728-34.

[11] Shoeb, M., Mahim, A., Mamun, M. I. R., and Nahar, N. 2016. "Organochlorine Pesticide Residues in Poultry Meats of Bangladesh." Croatian Journal of Food Science Technology 8 (1): 30-3.

[12] Mastoaska, K., and Matrices, M. 2006. "Rapid Sample Preparation Method for LC-MS/MS or GC-MS Analysis of Acrylamide in Various Food Matrices.” Journal of Agricultural and Food Chemistry 54 (19): 7001-8.

[13] Akerblom, M. 1995. "Environmental Monitoring of Pesticide Residues-Guidelines for the SADC Region.” Department of Environmental Assessment, Swedish University of Agricultural Sciences, Uppsala, Sweden.

[14] Achakzai, W. M., Saddozai, S., Baloch, W. A., Masood, 
Z., Rehman, H. U., and Ain, M. U. 2015. "Food and Feeding Habits of Glossogobius Giuris (Hamilton and Buchannan, 1822) Collected from Manchar Lake distt. Jamshoro, Sindh, Pakistan.” Global Veterinaria 14:
613-8.

[15] Codex Alimentarius Commission. 1993. Pesticides Residues in Food, Joint FAC/WHO Food Standards Programme, 23. 